\title{
Examining the relationship between narcissism and Machiavellianism levels in students receiving health education
}

\author{
Mehmet Salih Yıldırım1, Metin Yıldız ${ }^{2}$, Güray Okyar ${ }^{3}$ \\ ${ }^{1}$ Vocational School of Health Services, Igdir University School of Health, Igdir, Turkey \\ ${ }^{2}$ Department of Nursing, Agri Ibrahim Cecen University School of Health, Agri, Turkey \\ ${ }^{3}$ Department of Urology, Agri Ibrahim Cecen University School of Health, Agri, Turkey
}

Received: 2020-05-06.

Accepted: 2020-07-14

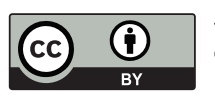

This work is licensed under a

Creative Commons Attribution 4.0 International License

J Clin Med Kaz 2020; 5(59):15-19

Corresponding author:

Metin Yıldız.

E-mail: yildizz.metin@gmail.com;

ORCID: https://orcid.org/0000-0003-0122-5677
Abstract

Objective: This research was conducted to examine the relationship between narcissism and Machiavellianism levels in students receiving health education.

Material and methods: This research, which is planned as a descriptive-correlational type, was carried out between March-April 2020 from students who received health education at Igdir University and Agri Ibrahim Cecen University.

Results: According to the findings obtained from the study, the total score average of the Narcissism Personality Inventory of the students was $5.353 \pm 2.70$. The total score average of Machiavellianism Scale was 53.029 \pm 6.53 . In addition, it was found that there is a positive statistically significant relationship between the Narcissism Personality Inventory total score and the Machiavellianism Scale total score.

Conclusion: It was found that the narcissistic level of the students receiving health education is at medium level and the machiavellist level is low. It is recommended to apply this study to students studying in different professions.

Key words: Machiavellianism, narcissism, student

\section{Introduction}

Narcissism, in general, means that the individual has an extreme loyalty and appreciation to his own spiritual and physical self or identity and individual cannot empathize $[1,2]$. In narcissistic personality disorder, the object is not something that a person does or produces, the object is something the person has for example, his body, appearance, health, wealth, etc. are such situations. The illness of this kind of narcissism is because there is no controlling element. The sick narcissist who thinks, "If I am" big "because of a qualification that I have, but not because of something I have achieved, then I do not have to deal with anyone, anything, and make no effort" so he cannot limit himself. He is buried more and more in his self-conceit and starts to isolate himself from everyone $[3,4]$.

Narcissism is necessary to sustain life, but narcissism can be dangerous for life [5]. The normal narcissistic object is a product that the individual creates with his own efforts, the individual can feel a narcissistic pride with the product (art, invention or vegetable-fruit) he has created by his profession. Since this object emerges through his own efforts, his interest in this success is constantly balanced with his interest in the work process and his materials. Creativity in the character of many narcissists can be explained by this process. Since the size results are positive, it can be accepted to a certain extent $[6,7]$. Another factor that may be associated with narcissism is Machiavellianism. Uçkun et al. found that there is a positive relationship between narcissistic admiration and Machiavellian behavior, the narcissistic personality affected the Machiavellian behavior [8]. Machiavellianism characterizes emotionally disconnected relationships, an interpersonal manipulative style, the desire to exploit others [9]. Machiavellianism is an unethical set of behaviors that have a guiding effect on others to achieve their intended goals. In the basis of Machiavellianism, it can be said that individuals do not have traditional moral understanding [10,11]. For those who embrace Machiavellian thought, whatever the pain it can inflict on people, the aims legitimize the means [11]. In the literature review, Aydoğan et al. found that narcissism did not differ by gender; it differed by according to demographic variables related to age, marital status and working time 
[12]. They found that the level of Machiavellianism did not differ at all according to demographic variables, and that there was a positive relationship between the narcissistic personality and the Machiavellian personality. Studies on health personnel in the international area have been found and it has been carried out due to the limited number of studies on students who have received health education and have not yet started their career. This research was carried out to reveal the relationship between Narcissist personality and Machiavellianism in students with health education, to determine the machiavellist and narcissist mindset of the students who will enter the working life in the future. Since these two thinking structures are more difficult to change in business life, this research was carried out to determine the interventions to be made earlier in the business life.

\section{Material and methods Study design}

This research, which is planned as a descriptivecorrelational type, was conducted between March-April 2020 from students who received health education at Iğdır University and Ağrı İbrahim Çeçen University. The target population of the study consisted of students who received health education at Iğdır University and Ağrı İbrahim Çeçen University. The sample of the study consisted of individuals who accepted to participate in the study from students who received health education at Iğdır University and Ağrı İbrahim Çeçen University.

\section{Data collection}

Data were collected using Personal Information Form, Narcissistic Personality Inventory and Mach IV Scale. After explaining the purpose of the research and obtaining verbal permission from those who voluntarily accepted to participate in the research, the data were collected online from the groups where students were made public announcements with the Google form prepared by the researchers.

\section{Data collection tools}

1. Personal Information Form: It consists of questions created by researchers and containing students' introductory features.

2. Narcissistic Personality Inventory: The original form of the scale was developed by Ames et al. In 2006 with 16 items [13]. Adaptation to Turkish was done by Atay (2009). There are 6 factors in the Turkish version of the scale, exhibitionism, superiority, domination, demand, exploitation and selfsufficiency. The reliability value of the scale is 0,652 [14]. In our study, Cronbach Alpha value was found to be 0.60 .

3. Mach IV Scale: The "Mach-IV" scale, developed by Christie and Geis (1970) to determine the level of Machiavellianism, was built on the characteristic features of effective manipulators parallel to the views proposed by Niccolo Machiavelli. In fact, these two authors have developed a group of phrases derived directly from Machiavelli's writings [15]. A Table containing the original expressions in this group of 71 expressions was included and was defined as "Mach-I" scale by the researchers. These 71 predetermined statements were later grouped as "Machiavellian" and "Non-Machiavellian". These grouped expressions are called the "Mach-II" scale. The "Mach-IV" scale, which has been arranged 71 expressions and reduced to 20 expressions that are thought to represent the best of Machiavellianism. The version of the expressions before the analysis was completed was defined as "Mach-III". The
Mach-IV scale measures persuasive and guiding beliefs that help individuals achieve their personal goals [16]. 10 of the 20 expressions created as a 5-point Likert type scale (1: Strongly Disagree 2: Disagree 3: Undecided 4: Agree 5: Strongly Agree) are Machiavellist (supporting the views of Niccolo Machiavelli) and 10 are non-Machiavellian (not supporting the views of Niccolo Machiavelli). The Machiavellian ones consist of the expressions Niccolo Machiavelli uses in his own works or arranged to give the same meaning, and the non-Machiavellian ones consist of expressions created by Christie and Geis (1970). The higher the average scores of individuals obtained from the survey, this shows that they tend to be Machiavellian. In the literature, the high scale score is generally considered as an undesirable situation in social terms [17]. In their research, Mandaci (2007) found the Cronbach $\alpha$ value of the Mach IV scale to be 0.77 [16]. In our study, Cronbach Alpha value was found to be 0.87 .

\section{Analysis of data}

The data were analyzed using the SPSS statistical package programme. Descriptive statistics, Kolmogorov-Smirnov, Mann-Whitney U, Kruskal-Wallis and Spearman correlation tests were used to in the analysis of data.

\section{Ethical principles}

Ethical approval was obtained from Ağrı İbrahim Çeçen University Scientific Research Ethics Committee and written permission was obtained from the institutions where the study would be conducted. Verbal permission was obtained from those who wanted to participate in the research by making necessary explanations to the individuals included in the research.

\section{Results}

$58.5 \%$ of individuals participating in the study are citizens of Turkey, $64.4 \%$ are female, $60.4 \%$ study at associate degree, $57.5 \%$ are in the second class, $50.2 \%$ are less than the expense of income, $74.4 \%$ don't know foreign languages, and the group the average age was found to be $21.06 \pm 2.69$ (Table 1).

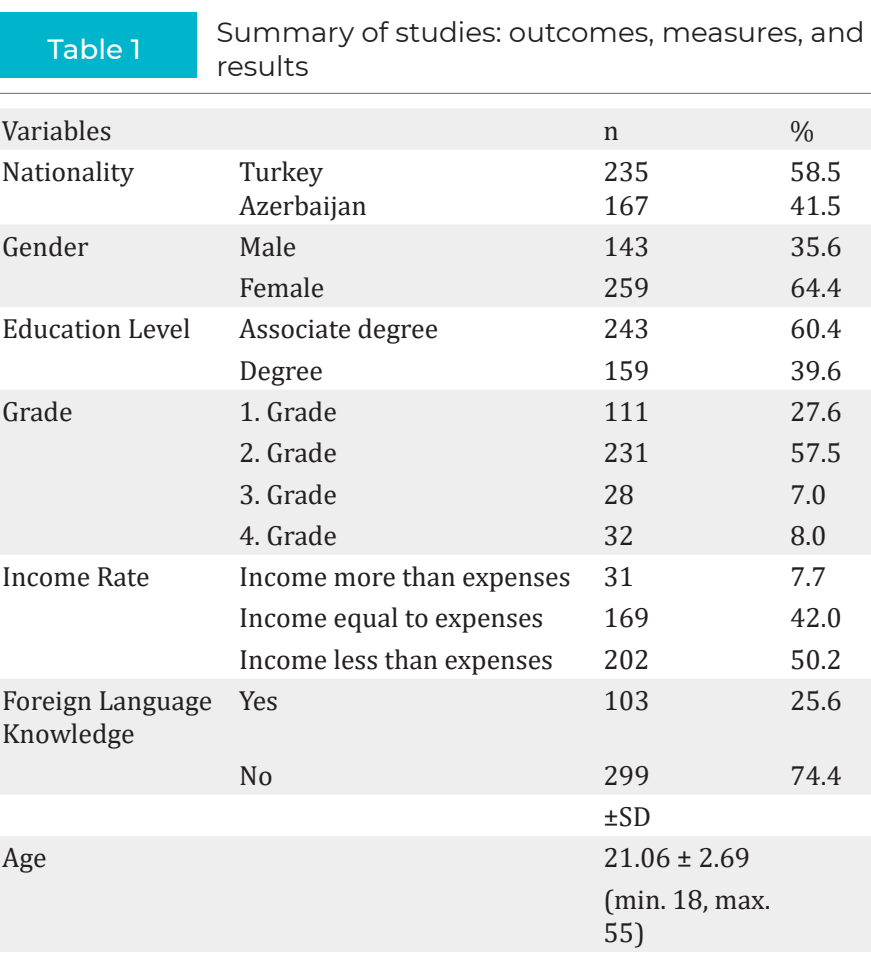


Narcissism Personality Inventory mean score was found to be statistically significantly higher in Azerbaijan nationals, men, associate degree students, those with higher income and foreign language speakers $(p<0.05)$. There was no difference between the groups in terms of the Narcissism Personality Inventory score average and the class they were studying $(\mathrm{p}>0.05)$ (Table 2$)$.

\section{Table 2}

Comparison of Students' Demographic Characteristics and Narcissism Personality Inventory Scores

\begin{tabular}{lllll}
\hline Variables & & $\mathrm{n}$ & Mean \pm SS & Statistic \\
Nationality & Turkey & 235 & $4.902 \pm 2.50$ & $\mathrm{U}=15488.50$ \\
& Azerbaijan & 167 & $5.988 \pm 2.84$ & $\mathrm{P}=0.000$ \\
Gender & Male & 143 & $5.979 \pm 2.88$ & $\mathrm{U}=14962.50$ \\
& Female & 259 & $5.007 \pm 2.53$ & $\mathrm{P}=0.001$ \\
Education & Associate degree & 243 & $5.711 \pm 2.71$ & $\mathrm{U}=15567.50$ \\
Level & Degree & 159 & $4.805 \pm 2.58$ & $\mathrm{P}=0.001$ \\
Grade & 1. Grade & 111 & $5.063 \pm 2.34$ & $\mathrm{x} 2 \mathrm{KW}=6.867$ \\
& 2. Grade & 231 & $5.493 \pm 2.78$ & $\mathrm{P}=0.076$ \\
& 3. Grade & 28 & $4.500 \pm 3.00$ & \\
Income & 4. Grade & 32 & $6.093 \pm 2.82$ & \\
Rate & Income more than & 31 & $5.871 \pm 2.59$ & $\mathrm{x} 2 \mathrm{KW}=7.342$ \\
& expenses & & & \\
Income equal to & 169 & $4.934 \pm 2.67$ & $\mathrm{P}=0.025$ \\
& expenses & & & \\
Foreign & Income less than & 202 & $5.623 \pm 2.70$ & \\
Kanguage & Yespenses & & & \\
Knowledge & No & 103 & $5.873 \pm 2.88$ & $\mathrm{U}=13361.50$ \\
& & 299 & $5.173 \pm 2.61$ & $\mathrm{P}=0.044$ \\
& & &
\end{tabular}

The Machiavellianism Scale mean score was found statistically significantly higher in women $(p<0.05)$. There was no difference between the Machiavellian Scale score average and the groups in terms of nationality, level of education, grade, income rate and foreign language knowledge $(\mathrm{p}>0.05)$ (Table 3$)$.

\section{Table 3}

Comparison of Students' Demographic Characteristics and Machiavellianism Level Scores

\begin{tabular}{lllll}
\hline Variables & & $\mathrm{n}$ & Mean $\pm \mathrm{SS}$ & Statistic \\
Nationality & Turkey & 235 & $52.838 \pm 6.074$ & $\mathrm{U}=18791.00$ \\
& Azerbaijan & 167 & $53.299 \pm 7.146$ & $\mathrm{P}=0.468$ \\
Gender & Male & 143 & $54.125 \pm 6.78$ & $\mathrm{U}=15805.50$ \\
& Female & 259 & $52.424 \pm 6.32$ & $\mathrm{P}=0.015$ \\
Education & Associate degree & 243 & $53.456 \pm 6.86$ & $\mathrm{U}=17608.50$ \\
Level & Degree & 159 & $52.377 \pm 5.96$ & $\mathrm{P}=0.133$ \\
Grade & 1. Grade & 111 & $53.369 \pm 5.79$ & $\mathrm{x} 2 \mathrm{KW}=2.666$ \\
& 2. Grade & 231 & $53.229 \pm 6.97$ & $\mathrm{P}=0.446$ \\
& 3. Grade & 28 & $51.107 \pm 6.36$ & \\
Income & 4. Grade & 32 & $52.093 \pm 5.73$ & \\
Rate & Income more than & 31 & $54.451 \pm 6.63$ & $\mathrm{x} 2 \mathrm{KW}=1.649$ \\
& Income equal to & 169 & $52.645 \pm 6.33$ & $\mathrm{P}=0.438$ \\
& expenses & & & \\
Foreign & Income less than & 202 & $53.133 \pm 6.68$ & \\
Language & Yes & & & \\
Knowledge & No & 103 & $52.970 \pm 6.01$ & $\mathrm{U}=15321.00$ \\
& & 299 & $53.050 \pm 6.71$ & $\mathrm{P}=0.939$ \\
& & &
\end{tabular}

According to the findings obtained from the study, it was found that the total score average of the students' Narcissism Personality Inventory was $5.353 \pm 2.70$ and the lowest score was 1 and the highest score was 13 . It was determined that the average score of the students' Narcissism Personality Inventory was moderate. The total score average of the Machiavellian Scale was found to be $53.029 \pm 6.53$ and the lowest score was 34 and the highest score was 78. It was determined that the average score of the students' Machiavellian Scale was low (Table 4).

Table 4

Narcissism Personality Inventory and Machiavellianism Scale Total Point Averages

\begin{tabular}{lll}
\hline & Mean \pm SS & Min- Max \\
Narcissism & $5.353 \pm 2.70$ & $1.00-13.00$ \\
Machiavellianism & $53.029 \pm 6.53$ & $34.00-78.00$
\end{tabular}

It was found that there is a positive statistically significant relationship between total score of Narcissism Personality Inventory and total score of Machiavellianism Scale $(\mathrm{p}<0.05)$ (Table 5).

\section{Table 5 The Relationship Between Average Scores of Narcissism Personality Inventory and the Machiavellianism Scale}

\begin{tabular}{llll}
\hline & Narcissism & Total & Score \\
& Average & & \\
& $\mathrm{r}$ & $\mathrm{p}$ & \\
Machiavellian Total Point Average & 0.146 & 0.003
\end{tabular}

\section{Discussion}

The effect of personality traits on person's attitudes and behaviors has attracted the attention of researchers for a long time. Despite the fact that personality traits such as narcissism and Machiavellianism have been studied a lot recently in the international arena, the number of studies in our country is very low [18-21]. The number of people with narcissistic personality and Machiavellian behavior is becoming more and more widespread in our society, and the number of people who are self-loving, arrogant, who think they are special and do not take into account the feelings and thoughts of other people around them also increases in higher education institutions [22,23]. In this context, it is aimed to examine the Narcissism and Machiavellianism levels of Turkish and Azerbaijani students who receive health education.

In our study, the total score average of Narcissism Personality Inventory was found to be medium. The result of the research is similar to the literature [24].

According to the findings obtained from the study, the average score of the Narcissistic Personality Inventory was found to be statistically significantly higher in students whose nationality is Azerbaijan $(p<0.05)$. When the literature is examined, there is no similar study. It is believed that the Azerbaijanis are more narcissistic due to the feeling that they are cared too much and much loved by the Turkish nation and hospitality for people of different nationalities of citizens in Turkey.

The Narcissistic Personality Inventory score mean was statistically significantly higher in male students $(p<0.05)$. In the studies carried out, similarly it was concluded that men exhibit more narcissistic personality than women $[25,26]$.

The Narcissistic Personality Inventory score average was 
found to be statistically significantly higher in students whose education level is associate degree $(\mathrm{p}<0.05)$. The higher average score in the group with lower education level indicates that this group is more narcissistic. The result of the work of Karakuş Ç. is similar to our findings [27].

The Narcissistic Personality Inventory score average was found to be statistically significantly higher in students who speak a foreign language $(\mathrm{p}<0.05)$. When the literature is examined, there is no similar study. This suggests that students who speak foreign languages are more narcissistic due to the feeling that they are more cared for by society. Narcissism Personality Inventory score mean was found to be statistically significantly higher in those with higher than income $(\mathrm{p}<0.05)$. In the study of Cai et al., the level of narcissism was found higher in people with high economic level [28].

The Machiavellianism Scale score mean was statistically significantly higher in male students $(\mathrm{p}<0.05)$. Similarly, it was found in the studies conducted that the level of Machiavellianism of women is higher than that of men $[29,30]$.

In our study, the average score for Machiavellianism Scale was found to be low. The result of the research is similar to the literature [31].

It was found that there is a positive statistically significant relationship between the total score of Narcissism Personality Inventory and the Machiavellianism Scale. Similar results were found in the studies conducted $[8,32]$. It can be said that as the narcissistic personality level of students increases in higher education institutions, the Machiavellian personality level increases.

\section{Conclusion}

The narcissistic levels of the students receiving health education were found to be medium and the Machiavellian levels were low. Individuals with narcissist and Machiavellian personality structure may cause unrest in the business environment, increase inefficiency, and decrease in job satisfaction. Since it is more difficult to change the Machiavellian and narcissist mindset of the students who will enter the business life in the future, it is recommended that this research be carried out before starting the business life in students who are educated in different occupational groups. In addition, it is thought that it is appropriate to examine the subjects like queen bee syndrome, mobbing and glass ceiling with both concepts or separately.

Disclosures: There is no conflict of interest for all authors.

\section{Acknowledgements:}

\section{Funding:}

\section{References}

1. Freud S. Narsizm üzerine ve schreber vakası. (Çev: SM. Tura., MB. Büyükkal.) [in Turkish]. İstanbul: Metis Yayınları. 2012.

2. Seward SK. "Are Narcissists Bad For Relationships Or Are Relationships Bad For Narcissits? The Effect Of Narcissism On Close Relationships," Narcissism And Relationships. Department of Psychology St. Francis Xavier University. 2007.

3. Foster JD, Campbell WK. Are there such things as "Narcissists" in social psychology? A taxometric analysis of the narcissistic personality inventory. Personality and Individual Differences. 2007; 43(6):1321-1332. https://doi.org/10.1016/j.paid.2007.04.003

4. Doğaner İ. Narsisistik kişilik bozukluğu: Tarihçe, tanı ve ayırıcı tanı [in Turkish]. Ege Psikiyatri Sürekli Yayınları. 1996; 1(3):341-352.

5. Lasch C. Narsisizm kültürü. (Çev: S. Öztürk., Ü.H. Yolsal.) [in Turkish]. Ankara: Bilim ve Sanat. 2006.

6. Çelik H. Üniversite birinci sınıf öğrencilerinin saldırganlı tepkileri, bağlanma tarzları ve kişilerarası semaların incelenmesi [in Turkish]. (Yayımlanmamış Yüksek Lisans Tezi). Marmara Üniversitesi Eğitim Bilimleri Enstitüsü, İstanbul. 2006.

7. Cramer P. Narcissism through the ages: What happens when narcissists grow older? J. Res. Pers. 2011; 45(5):479-492. https://doi. org/10.1016/j.jrp.2011.06.003

8. Uçkun CG, Üzüm B, Uçkun S. Narsist kişiliğin makyavelist davranışlara etkisi: Kocaeli Üniversitesi özel güvenlik öğrencileri örneği [in Turkish]. AKÜSBD. 2018; 20(2):139-154. https://doi.org/10.32709/akusosbil.422221

9. Brewer G, Abell L. Machiavellianism, relationship satisfaction, and romantic relationship quality. Eur J Psychol. 2017; 13(3):491-502. https://doi.org/10.5964/ejop.v13i3.1217

10. Ináncsi T, Láng A, Bereczkei T. Machiavellianism and adult attachment in general interpersonal relationships and close relationships. Eur J Psychol. 2015; 11(1):139-154. https://doi.org/10.5964/ejop.v11i1.801

11. Ayan A. Makyavelist kişilik eğilimi algılarının yaşamın anlamı ve yaşam doyumu üzerine etkisi. [in Turkish]. CBÜ IIIBF Yönetim ve Ekonomi Dergisi. 2017; 24(1):53-72. https://doi.org/10.18657/yonveek.307496

12. Aydoğan E, Serbest S. İş yerinde karanlık üçlü: bir kamu kuruluşunun iç denetim biriminde araştırma [in Turkish]. Sayıştay Dergisi. 2016; 101:97-121.

13. Ames DR, Rose P, Anderson CP. The NPI-16 as a short measure of narcissism. Journal of research in personality. 2006; 40(4):440450. https://doi.org/10.1016/j.jrp.2005.03.002.

14. Atay S. Narsistik Kişilik Envanteri’nin Türkçe’ye Standardizasyonu. Gazi Üniversitesi İktisadi ve İdari Bilimler Fakültesi Dergisi. 2009; 11(1).

15. Christie R, Geis F. Studies in Machiavellianism. New York: Academic Press. 1970.

16. Mandacı G. Makyavelist Tutumların Etik Algısı ve Demografik Faktörler Açısından Değerlendirilmesi: Bankacılık Sektöründe Bir Araştırma. Yayımlanmamıș Yüksek Lisans Tezi). Hacettepe Üniversitesi/Sosyal Bilimler Enstitüsü. Ankara. 2007.

17. Atakan Ş. İşletme etiğinde makyavelizm: Görsel basın haber programları iş görenlerinin makyavelizm düzeylerini belirlemeye yönelik bir çalışma [in Turkish]. (Yayımlanmamış Yüksek Lisans Tezi). Hacettepe Üniversitesi Sosyal Bilimler Enstitüsü. Ankara. 2002.

18. Jonason PK, Webster GD. The dirty dozen: A concise measure of the dark triad. Psychol. Assess. 2010; 22(2):420-432. https://doi. $\operatorname{org} / 10.1037 / \mathrm{a} 0019265$

19. Skeem JL, Polaschek DL, Patrick CJ, Lilienfeld SO. Psychopathic personality: Bridging the gap between scientific evidence and public policy. Psychol Sci Public Interest. 2011; 12(3):95-162. https://doi.org/10.1177/1529100611426706 
20. Jones DN, Paulhus DL. The role of impulsivity in the dark triad of personality. Personality and Individual Differences. 2011; 51(5):679-682. https://doi.org/10.1016/j.paid.2011.04.011

21. Schyns B. Dark personality in the workplace: Introduction to the special issue. Appl Psychol. 2015; 64(1):1-14. https://doi.org/10.1111/ apps. 12041

22. Kanten $P$, Yeşiltaş M, Arslan R. Kişiliğin karanlik yönünün üretkenlik karşıtı iş davranışlarına etkisinde psikolojik sözleşmenin düzenleyici rolü. [in Turkish]. Atatürk Üniversitesi İktisadi ve İdari Bilimler Dergisi. 2015; 29(2):931-259. https://doi.org/10.16951/ iibd.40167

23. Özsoy E. Türkiyede iş tatmini araştirmalarinin genel görünümü. İçinde: Kutanis ÖR, editör. Türkiye'de örgütsel davranış çalışmaları [in Turkish]. 1. Bask1. Ankara: Gazi Kitapevi. 2015; 103-23.

24. Temel D. The role of perceived social problem solving, narcissism, self-esteem and gender in predicting aggressive behaviors of high school students. (Unpublished Master's Thesis). The Graduate School of Social Sciences of Middle East Technical University. Ankara. 2008.

25. Barry TD, Thompson A, Barry CT, Lochman JE, Adler K, Hill K. The importance of narcissism in predicting proactive and reactive aggression in moderately to highly aggressive children. Aggress Behav. 2007; 33(3):185-197. https://doi.org/10.1002/ab.20198

26. Eren Z. Spor salonuna giden yetişkinlerin yeme tutumları, sosyal fizik kayglları ve narsistik yapılanmaları arasındaki ilişki [in Turkish]. (Yayımlanmamış Yüksek Lisans Tezi). Maltepe Üniversitesi Sosyal Bilimler Enstitüsü Psikoloji Anabilim Dalı Klinik Psikoloji Programı. İstanbul. 2012.

27. Karakuş Ç. Lise öğrencilerinde psikolojik savunmalar açısından narsisizm ve benlik saygısının karşılaştırılması [in Turkish]. (Yayımlanmamış Yüksek Lisans Tezi). İstanbul Sabahattin Zaim Üniversitesi Sosyal Bilimler Enstitüsü. İstanbul. 2017.

28. Cai H, Kwan VSY, Sedikides C. A sociocultural approach to narcissism: The case of modern China. Eur. J. Pers. 2012; 26(5):529-535. https://doi.org/10.1002/per.852

29. Saccarelli E. The Machiavellian Rousseau: Gender and family relations in the discourse on the origin of inequality. Political theory, 2009; 37(4), 482-510. https://doi.org/10.1177/0090591709335228

30. Singer JE. The use of manipulative strategies: Machiavellianism and attractiveness. Sociometry, 1964; 128-150. https://doi. org $/ 10.2307 / 2785711$

31. Özcihan T. Organizasyonlarda stratejik duygusal zeka kullanımı makyavelizm ilişkisi ve çatışma yönetimine yansıması: Tasarım mühendisliğinde bir araştırma [in Turkish]. (Yayımlanmamış Yüksek Lisans Tezi). Anadolu Üniversitesi, Eskişehir. 2014.

32. Bolelli ÖÜM. Karanlık Üçlünün (Narsisizm, Makyavelizm ve Psikopati) Yöneticilerin Sosyal Güç Kullanımına Etkilerinin İncelenmesi. Danışma Kurulu, 86. 